\title{
Complex Standardization as the Factor of Flexibility and Competitive Ability*
}

\author{
Gustav Tomek, Věra Vávrová \\ Czech Technical University in Prague, Technická 2, 16627 Prague 6, the Czech Republic
}

\begin{abstract}
Research, performed by the authors proved that one of the most significant factors affecting the increase in flexibility and competitive ability of a firm is the conceptual, complex intra-plant standardization. The enterprise implementing the standardization is capable of flexible responding to customer's demands for the assortment, accelerates considerably research, and offers satisfactory delivery terms. That means the selection of types of the input factors and the method how to use them, the selection of working procedures and procedures of intermediary consumption, definition of the relations in the process of control, rational structure of the final products etc.. The permanent innovative atmosphere is presupposed.
\end{abstract}

Keywords: standardization, flexibility, competitiveness, efficiency

\section{Corporate Standardization Principle}

Standardization is necessary to be understood in principle as dynamics considering yet systematic process of selection, unification, and purposeful stabilisation of individual options of solution, procedures, input elements, their combinations, as well as output elements, activities, and information in the process of company management and in its individual components. The purpose of standardization is decreasing the varieties, accidents in a controlled process, as well as securing unambiguousness of interpreting decisions made, approaches, as well as elements involved. Technology development, innovative tendencies, and changes in surrounding area bring a number of new elements to production management, i.e., both in terms of complexity of products/production, and in terms of the possibility of selecting input elements, procedures, equipment, records-keeping, supervision over production process etc.. This natural diversification must be in terms of the controlled entity constantly reflected into a purposefully created and dynamically adjusted standardisation, which secures a higher stability, overview, definiteness and last but not least economy of production process. The matter is to determine a certain set of technical and economic standards, correlations, and limits etc.. We normally encounter in management process that serves namely for intra-company planning and management.

The process of standardization is not contradicting the required innovative climate, or research and

\footnotetext{
* This essay originated as a result of a research project entitled, MSM 6840770038 Decision Making and Control for Manufacturing III, TU 11 Management of a company and its competitive ability.

Gustav Tomek, DrSc., professor, Department of Economics, Management and Humanities, Faculty of Electrical Engineering, Czech Technical University in Prague.

Věra Vávrová, Ph.D., CSc., associate professor, Department of Economics, Management and Humanities, Faculty of Electrical Engineering, Czech Technical University in Prague.
} 
development progress at all. The principle of proper standardisation implementation is namely orientation to real, and perspective economic solutions caused by constant marketing research, including buying market research and assessment of own strength and weaknesses compared to competition. An important element of full-scale standardization is also an analysis of market globalisation impact (Aumayr, 2006; Tomek \& Vávrová, 2007, 2009).

The starting point in such a full-scale standardization is: "application of methods and measures, which aim at limiting non-purposeful variety of activities within the company", i.e., selecting types and method of using input elements, selection of working and other procedures, clear definition of correlations in management process etc..

With regard to the above-stated facts, it is, inter Alia, possible to explain why deal with full-scale standardization, as a principal issue of production and buying management. The reasons are namely the following:

(1) Standardization is a basis for creating basic information database used by the entire company (e.g., a standard determining consumption of a certain type of material for a certain product is required for quotation and final calculation, planning of buying and actual buying, for limiting storage capacity, for control and records-keeping in production etc.). Unification of all elements of company organisation and management.

(2) Standardization — as narrowing down many solutions available — is paradoxically also a way of solving various views at a competitive advantage in terms of marketing and production. Equally, it solves the dispute between the construction and buying department (the first one requiring variety, the other one more modesty), between construction and technology, between buying and production etc.. It provides building blocks of input and output elements, which, thanks to applying an optimum choice enable complying with various wishes customers may have. At the same time, it provides all information (salary, capacity, etc.) for decision-making about new requirements or changes. Despite that, it is necessary to respect the opinion that unsuitable standardization may act as a brake to the innovative process, and thereby limit corporate market orientation.

Standardization may be confronted with other corporate development presumptions such as conformability, continuity, and namely creativity. The correlation is shown in Figure 1. It is namely conformability and continuity: A company that thoroughly accepts and applies market orientation is namely led by an effort to achieve as much conformability as possible in terms of opportunities to comply with customer requirements and at the same time by maintaining innovative steps as regards technical, technologic, economic, and social trends. Yet, market orientation must also count on certain continuity required by a specific customer segment (use of traditional materials, procedures, etc., as a basis for differentiation or image of products). A separate problem of continuity is the area of management, records-keeping, implementation of changes and their reflection into technical documents and production or buying documentation. The same applies to the relation between creativity and standardization. No creative activity can be unlimited, and each activity has tied to the previous and following ones. That requires a gradual accommodation of all agents. Standardization here plays a role of direction setting using positive motives for changes (Beckmann, 2004; Belz \& Bieger, 2004; Bruhn \& Hadwich, 2006).

\section{Necessity of Full-Scale Standardization Existence}

The result of full-scale standardization is standards of production process management. These are based on and at the same time represent a set of all measures and activities leading towards both basic agents of the production process and all activities originating in the production process were limited to a purposeful level. Individual areas of standardisation are merely relatively isolated activities, as the production process creates 
necessary correlations among those, which presume that the standardization base of a company includes all factors and aspects of corporate activities. Upon introducing a certain systemisation, we then differentiate individual phases/areas of full-scale standardization:

- Standardization of management process;

- Standardization of material input elements of production process;

- Standardization of activities and methods of changes in production process;

- Standardization of correlations in consumption and use of production agents;

- Standardization of combinations upon operative production management;

- Standardization of output elements of production process.

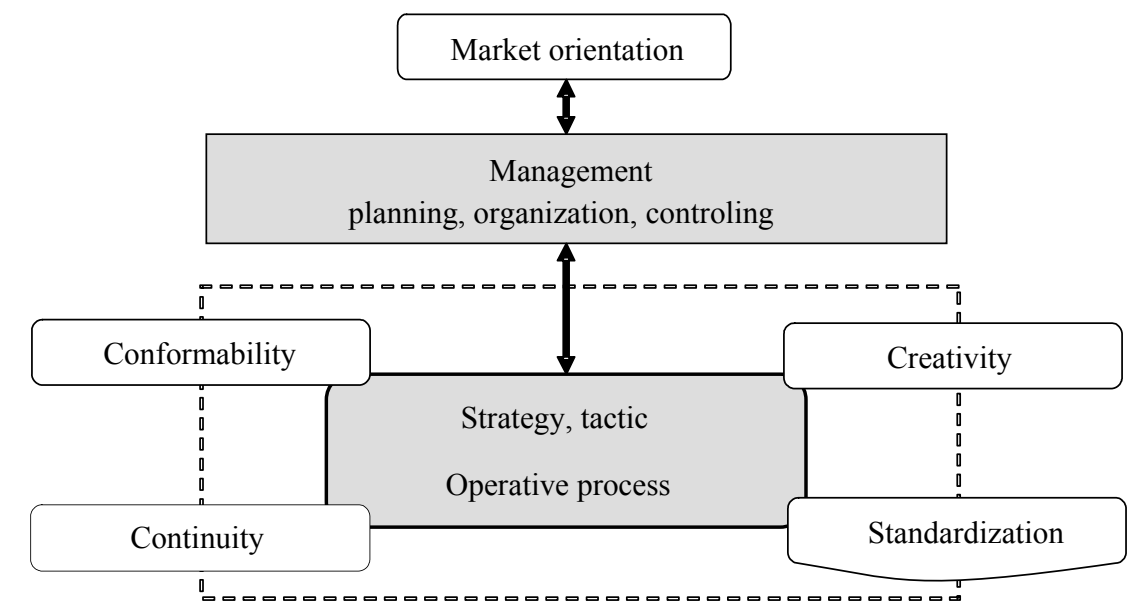

Figure 1. Standardization and conformability, continuity, creativity, standardization.

Standardization has a number of benefits to organisation and management of a company. They are namely:

- Rational organisation of production, technical, economic, and commercial, personnel, and other activities of the company;

- Unification of information and securing its clear explanatory ability;

- Applying economy of scale to production process and thereby simplifying its organisation and management, as well as decreasing costs, reflecting positively in a way towards a corporate competitive advantage;

- Specialisation development;

- Upgrading workmanship and quality technical level;

- Effective use of tools;

- Economy of all processes securing production;

- Respecting market demand, namely as regards accommodation of options and product range composition to customer requirements;

- Cutting down on lead times as a result of reducing average prep times and actual production periods;

- Introduction of a complex quality control system, application of production and control automation;

- Transparency of production records-keeping also in terms of consumption of individual production process agents;

- Upgrading labour safety and eliminating work task difficulties. 
Applying the latest scientific and technical know-how as well as complex marketing research results (analyses of customers, competition, distribution, surrounding area, and own strengths and weaknesses) keeps bringing new requirements for information and standardization base of each company. Full-scale approach is a more advanced one in terms of quality, abstracting from the typical understanding as an issue of technical standardization or a mere guidance to a process of diversification. As stated above, standardization is namely to suppress undesired variety, which could cause imbalance among individual parts and whole of systems and negatively impact on efficiency of their behaviour. These interventions may concern a production factor, products, a combination of factors, activities upon their use etc.. Individual standards in the widest sense of the word become a tool expressing a uniform, relatively time-stable, binding regulation on properties, scope of relations and combinations of factors of a given process and their functioning within the frame of the actual process. In market economy, it is necessary to understand and use standardization as a systematic effort heading towards such an arrangement and solution of production factors, methods of their use and control, which is based on purposeful application of the latest scientific and technologic know-how and as a whole enables a company to fulfil market demands and better serve the market in general.

\section{Standardization as a Corporate Flexibility Factor}

\section{Speeding-up Marketing of a Product}

Standardization in this case has a positive impact on preparation and implementation of a new order due to the following reasons:

(1) Standardized solution requires application of an appropriate principle in construction and technologic documentation. Upon building block production every assembly phase (final, set, subset, part) is covered in a separate construction and consequently technological documentation. Individual phases obviously occur a multiple of times in various products and in various combinations. The documentation must always secure easy orientation in relation to a higher level-lower level of a product. The same applies also to technologic procedures, which are also created based on individual building blocks, in relation to drawing (part) numbers. All of these enable use of the existing individual input for technical preparation of production and technical and economic standards upon creating new products (based on building blocks).

(2) Existence of standards applicable to input elements, technological and other procedures then speeds up the actual organisation of production process and implementation of an order prepared in terms of construction and technology (Hofbauer \& Bauer, 2004; Palupski, 2002).

Next to the potential of time saving, there are prerequisites for the production process to comply with growing dynamics of market needs, requirement for increasing competitive potential, thereby resolving the indicated dispute between marketing/sales and production, which seems to be a fundamental problem in willingness to co-operate on the part of the integrating agent of market demands and their fulfilment vehicle. Standardization in this sense requires, and at the same time, enables optimisation and restructuring of production process in the sense of eliminating non-standard activities and intensifying economy of scale in production as complies with standardization potential (creating universal building blocks). As production in relation to increase in individualisation in market demands must also have a potential for answering non-standard requirements, production organisation must be arranged by parallel and substitute processes etc.. 
The indicated use of all-inclusive standardization:

- Speeds up the process of production technical preparation;

- Speeds up the process of securing repeated input elements;

- Speeds up the process of actual product creation process management and planning, i.e., namely production management and planning;

- Speeds up the entire process of operative management of production (planning and management of production, purchase, and sales, production operative records-keeping, dedicated production management and control methods, including variation procedures);

- Enables extension of multiple option offer to potential and existing customers thanks to production based on building blocks;

- Assists in fast accommodation of the market and timely offer of solutions to customer needs.

\section{Fulfilling Customer Requirements}

Full-scale standardization is paradoxically also an important factor in fulfilling the requirement or product multiple options. It enables selection of a product based on customer requirements of the given standardized set of building blocks, which, of course, in optional combinations of blocks enables both alternatives of standardized parts and alternative addition of parts, which can be further used within the frame of the building block set (Belz \& Bieger, 2004; Corsten \& Gabriel, 2002; Corsten \& Gössinger, 2001; Hofbauer \& Bauer, 2004). Customer co-operation scheme upon selecting a final product is shown in Figure 2.

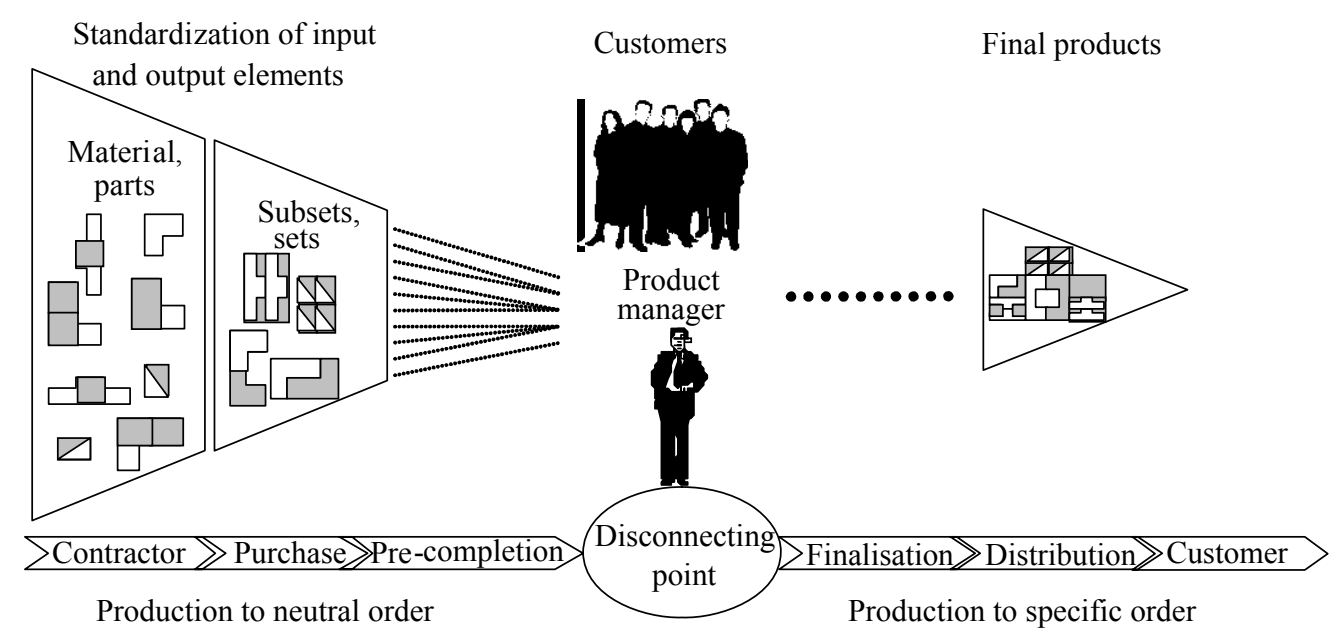

Figure 2. Standardization and customer.

As described above, full-scale standardization will result namely in:

- Cutting down on the process of research and development, and the entire chain actually: offer and order procedure - order clarification - production technical preparation — buying-production-sales;

- Cutting down on lead times in general;

- A more effective and more flexible arrangement for adequate production factors;

- Rational utilisation of resources;

- Building-up a competitive advantage, be it by way of the lowest costs or product differentiated by its quality; 
- Possibilities of easier reflection of changes into existing sales, production, and procurement operative plans.

\section{Production Management Aspect (Material Flow Control)}

If we focus on the actual production process, then it is necessary to connect fully application of the standardization advantages with the requirement for:

- Production process optimisation;

- Production process restructuring;

- A new procurement strategy;

- Flexible management in individual supervision areas.

The basis of solving the problem of satisfying customer individual needs is namely standardization of output elements, i.e., standardization of individual parts of products, which leads to thorough application of production building block system, resulting in a possibility to offer limited series to custom-made final products utilising serial to mass production parts. The objective of production management is then suitably dividing the production material flow into two parts, i.e., Production to neutral order and Production to specific order.

The first one represents production of parts (parts, sets, subsets), which form a basis of final product building block system and can be produced with all the advantages brought to modern production by the possibility of producing in large batches. Therefore, in the corporate value-creation chain, which can be characterised by the following sections: selection of contractor-buying — pre-completion phase (production of parts), completion phase (production of subsets and sets) — finalisation phase (assembly of final products) — distribution, there is a struggle for optimal location of a disconnecting point in this chain, which represents exactly division of production into the part produced regardless of the end customer (neutral in terms of customer) and with regard to specific customer requirements (customer-specific). At this point of disconnection on the material production flow vector a new vector is connected, representing the information flow, which can be characterised by the following time sections: dealing with customer - processing an offer — construction processing of an order - technological processing of an order, followed by links in the actual production material production flow (production of specific parts, namely final assembly). A successful ratio of connecting these vectors at the point of disconnecting the material production flow is considered, given the research carried out, to be the following ration of orders:

- $20 \%-30 \%$ of standard production;

- $60 \%-70 \%$ of selection of offer;

- $10 \%-20 \%$ of construction according to customer requirements.

The company thus keeps revealing the fact that fulfilment of customer individual requirements is possible and can lead the company towards achieving a competitive advantage. Individualisation finds its place in mass production by increasing, from the customer viewpoint, the number of:

- Standard products with specific options according to customers;

- Standard products with specific options as offered (Vahrenkamp \& Siepermann, 2004; Warnecke \& Braun, 1999; Zäpfel, 1996; Zäpfel \& Piekarz, 1996; Schöttner, 1999; Schulte, 2005).

\section{Conclusion}

Newer production concepts generally focus on being able to balance as economically as possible, the processes according to orders in relation to processes based on appropriate prognoses. Production management is 
to verify to what extent individual types of processes may be mutually replaced. Therefore, in practice, it is necessary to count on utilising more approaches within a single production company, which will then reflect in operative planning methods. In typical conditions of small-scale serial to serial production the most advantageous procedure is one where in the initial production phases (pre-completion and completion phases) economy of scale is applied in production orders made based on prognoses, possibly also on customer specifications, as allowed by building block based production. That is linked to planning according to the status of unfinished production supplies, in some cases even distribution rhythm, and at the final stage (assembly), individual or small-scale serial production to customer specifications is applied, linked to planning according to forecasts or orders received.

The company thus may successfully operate through optimisation of its value creation chain and level of pre-stocking with material and parts in order to launch a new view of competition by gaining a competitive advantage through improved supplier service and/or lower price (thanks to economy of scale at certain phases of production) within the frame of individualisation of needs, which represents a principal challenge in current corporate development.

Approach to full-scale standardization must also be subject to constant all-inclusive assessment. In order to preserve the benefits of standardization, it is necessary to keep a balance between positive stability and growing dynamics. This is about very sensitive management level of decision-making. It is not possible to give way only to new, creative directions and ideas without applying a certain continuity of current management, organisation and other systems. Constant motion, often accompanied by short-term temporary changes, cannot contribute to effective corporate development, and on the contrary, it can cause excessive extra costs, stress situations, which bring constant accommodation of workers, and cause uncertainty in rules and responsibilities, standardized basis etc.. The process of standardization cannot be contradictory to the requirement for an innovative climate, or support of research and development. This is a process that is systematically updated and improved on. That is what follows from standardization principles (Tomek \& Vávrová, 2008, 2009).

\section{References}

Aumayr, K. J. (2006). Erfolgreiches produktmanagement. Wiesbaden: Gabler Verlag.

Beckmann, H. (2004). Supply chain management. Berlin, Heidelberg: Springer.

Belz, C. H., \& Bieger, T. (2004). Customer value. St. Gallen: Verlag Thexis.

Bruhn, M., \& Hadwich, K. (2006). Produkt-und servi cemanagement. München: Verlag Vahlen.

Corsten, D., \& Gabriel, C. H. (2002). Supply chain management erfolgreich umsetzen. Berlin, Heidelberg: Springer.

Corsten, H., \& Gössinger, R. (2001). Einführung in das supply chain management. München: Oldenburg Verlag.

Hofbauer, G., \& Bauer, C. H. (2004). Integriertes beschaffungs marketing. München: Verlag Vahlen.

Palupski, R. (2002). Management von beschaffung, produktion und absatz. Wiesbaden: Gabler.

Schöttner, J. (1999). Produktdatenmanagement in der fertigungsindustrie. München: Carl Hanser Verlag.

Schulte, C. H. (2005). Logistik-Wege zur optimierung der supply chain (4th ed.). Auflage, München: Verlag Valen.

Tomek, G., \& Vávrová, V. (2007). Řízení výroby a nákupu. Praha: GRADA.

Tomek, G., \& Vávrová, V. (2008). Marketing od myšlenky krealizaci (2nd ed.). Praha: Professional publishing.

Tomek, G., \& Vávrová, V. (2009). Jak zvýšit konkurenční schopnost firmy. Praha: C. H. Beck.

Vahrenkamp, R., \& Siepermann, C. H. (2004). Produktions management. München: Oldenbbourg Verlag. Warnecke, H. J., \& Braun, J. (1999). Vom Fraktal zum produktions netzwerk. Berlin, Heidelberg: Springer-Verlag.

Zäpfel, G. (1996). Grundzüge des Produktions-und logistik-management. Berlin, New York: Walter de Gruyter.

Zäpfel, G., \& Piekarz, B. (1996). Supply chain controlling. Wien: Wirtschaftsverlag C. Überreuter. 